\title{
The influence of dietary zinc source and coccidial vaccine exposure on intracellular zinc homeostasis and immune status in broiler chickens
}

\author{
Catalina Troche ${ }^{1} \dagger$, Susan D. Eicher ${ }^{2}$ and Todd J. Applegate ${ }^{1 *}$ \\ ${ }^{1}$ Department of Animal Sciences, Purdue University, West Lafayette, IN, USA \\ ${ }^{2}$ Livestock Behavior Research Unit, United States Department of Agriculture, Agricultural Research Service, West Lafayette, \\ IN, USA
}

(Submitted 11 September 2014 - Final revision received 1 April 2015 - Accepted 14 April 2015 - First published online 16 June 2015)

\section{Abstract}

Coccidia are protozoal parasites which compromise mucosal integrity of the intestine, potentiating poultry morbidity. The host's Zn status influences the course of infection. Therefore, two experiments were designed to determine how supplemental $\mathrm{Zn}$ regimens impacted jejunal and caecal immune status and $\mathrm{Zn}$ transporter expression. Coccivac ${ }^{\circledR}$ - $\mathrm{B}$ was administered weekly at ten times the recommended dose as a mild coccidial challenge (10CV). Zn was provided through a basal diet, supplemental zinc sulfate ( $\mathrm{ZnSO}_{4}$ ), or a supplemental 1:1 blend of $\mathrm{ZnSO}_{4}$ and Availa ${ }^{\circledR}-\mathrm{Zn}$ (Blend). Mucosal jejunum (Expt 1) and caecal tonsils (Expt 2) were evaluated for intracellular Zn concentrations and phagocytic capacity. Messenger expression of Zn transporters ZnT5, ZnT7, Zip9 and Zip13 were investigated to determine Zn trafficking. With $10 \mathrm{CV}$, phagocytic capacity was decreased in jejunal cells by $2 \%$. In the caecal tonsils, however, phagocytic capacity increased with challenge, with the magnitude of increase being more pronounced with higher dietary $\mathrm{Zn}(10 \mathrm{CV} \times \mathrm{Zn}$ interaction; $P=0 \cdot 04)$. Intracellular $\mathrm{Zn}$ within caecal tonsils was found significantly reduced with $10 \mathrm{CV}(27 \%, P=0.0001) .10 \mathrm{CV}$ also resulted in an overall increase in the ratio of Zip:ZnT transporters. With the exception of Zip13 transporter expression, dietary Zn source had little impact on any of the measured cellular parameters. Thus, intestinal mucosal tissues had reductions in intracellular free Zn during coccidial challenge, which was coupled with an upregulation of measured Zip transporters. This suggests that under coccidial challenge, intestinal cells attempt to compensate for the drop in intracellular Zn.

Key words: Zinc transporters: Coccidia: Broilers: Zinc sources

Coccidiosis is a protozoal infection responsible for high morbidity and substantial economic loss to the poultry industry $^{(1,2)}$. Pathogenesis of coccidiosis is attributed to damage of the mucosal lining, which results in growth depression and malabsorption of macro- and micronutrients $^{(3-7)}$. In broiler chickens, coccidial infection decreased levels of serum $\mathrm{Fe}$, while increasing levels of $\mathrm{Cu}^{(6,7)}$. Plasma Zn was found decreased in birds inoculated with Eimeria acervulina or Eimeria tenella compared to their unchallenged cohorts $^{(8-12)}$. This decrease in plasma $\mathrm{Zn}$ corresponded with increased liver $\mathrm{Zn}$ content $^{(7,12)}$. Metallothionein (MT) is a cysteine-rich $\mathrm{Zn}$ binding protein, which is upregulated during the acute phase response through a mechanism associated with oxidative stress ${ }^{(13-15)}$. Infection with E. tenella increased Zn-bound MT content in the liver by $91 \%{ }^{(12)}$. Observable increases in MT-bound $\mathrm{Zn}$ are not exclusive to coccidiosis. Immune stressors such as bacterial cell wall components and inflammatory cytokines increased liver $\mathrm{Zn}$ content $^{(16-18)}$. While MT is the major eurokayotic storage protein for $\mathrm{Zn}$, transport of $\mathrm{Zn}$ to cytosolic proteins is mitigated by two families of contra-directional $\mathrm{Zn}$ transporters.

Both $\mathrm{Zn} / \mathrm{Fe}$-regulated transporter (ZRT/IRT-like) proteins (Zip) and cation diffusion facilitator (CDF) $\mathrm{Zn}$ transporters $(\mathrm{ZnT})$ are responsible for intracellular $\mathrm{Zn}$ trafficking ${ }^{(19)}$. The evaluation of $\mathrm{Zn}$ transporters within the avian species is relatively new to the literature; however, $\mathrm{Zn}$ transporter function is highly conserved between species ${ }^{(19,20)}$. The current NCBI 2011 assembly for Gallus gallus has four complete coding sequences: ZnT5, ZnT7, Zip9 and Zip13. In the context of gastrointestinal function, ZIP 4 and ZnT1 have been extensively studied in mammals ${ }^{(21-23)}$. However, ZnT5, ZnT7, ZIP9 and ZIP13 transporters are associated with the transGolgi network and are involved in major signalling pathways, for example phosphorylation of extracellular signal-regulated

Abbreviations: $10 \mathrm{CV}$, ten times the recommended dosage of Coccivac ${ }^{\circledR}$-B; MFI, median fluorescent intensity; MT, metallothionein; Zip, Zn influx transporter; ZnT, Zn efflux transporter.

*Corresponding author: T. J. Applegate, fax +1 765494 9346, email applegt@purdue.edu

†Present address: Department of Food Science and Human Nutrition, University of Florida, Gainesville, FL, USA. 
kinase, protein kinase $\mathrm{B}$, and transforming growth factor$\beta^{(24-27)}$. ZnT7 was found to be particularly critical for $\mathrm{Zn}$ uptake in the murine small intestine ${ }^{(28)}$. Therefore, it is likely that these transporters would be influenced by inflammation and $\mathrm{Zn}$ status in poultry. In confirmation of this observation, ZnT5 and 7 were found to be critical to the function of alkaline phosphatases (mucosal protective proteins) ${ }^{(29,30)}$.

Influx of $\mathrm{Zn}$ into the cytosol is coordinated by ZIP proteins localised to the plasma membrane, vesicles, and/or the Golgi complex $^{(19,20)}$. Efflux of $\mathrm{Zn}$ out of the cytosol and into vesicles and/or the Golgi complex is mediated by $\mathrm{ZnT}$. Extracellular stimuli including but not limited to cytokines ${ }^{(31)}$, glucose $^{(32)}$ and estrogens ${ }^{(33)}$ have been shown to alter $\mathrm{Zn}$ homeostasis via $\mathrm{Zn}$ transport proteins. Directionality of net $\mathrm{Zn}$ transport appears to be dependent on cell type: for example stimulated monocytes and granulocytes increased free intracellular Zn, activated dendritic cells decreased intracellular $\mathrm{Zn}$, and lymphocytes appeared to have no significant change ${ }^{(34,35)}$. The shift in intracellular $\mathrm{Zn}$ content was attributed to a shift in transporter expression ${ }^{(34,35)}$. In dendritic cells, the control ratio of measured Zip:ZnT mRNA was 0.67 , and when stimulated with lipopolysaccharide, this ratio decreased to $0 \cdot 25^{(35)}$. This shift led to an overall movement of $\mathrm{Zn}$ out of the cytosol, ultimately reducing free intracellular $\mathrm{Zn}^{(35)}$.

These data show that cellular Zn homeostasis, controlled by ZIP and ZnT transporters as well as MT, is influenced by extracellular stimuli. These cellular changes can then lead to changes in tissue homeostasis ${ }^{(36)}$. The afore-mentioned studies focus on changes in hepatic $\mathrm{Zn}$ during immune stimulus, and make a strong case for $\mathrm{Zn}$ sparing within the liver ${ }^{(37,38)}$. However, the liver is the downstream of the intestinal mucosa, which is coccidia's main effector tissue. Early studies were unable to determine any effect of coccidial infection on intestinal $\mathrm{Zn}$ content ${ }^{(7)}$. These studies were based on total $\mathrm{Zn}$ content within dry tissue, and were thus unable to differentiate between membrane- and/or protein-bound $\mathrm{Zn}$ and free intracellular $\mathrm{Zn}$. The experiments presented herein were designed to test the hypothesis that $\mathrm{Zn}$ transport and immune function were altered with exposure to coccidial challenge and dietary $\mathrm{Zn}$ regimen. Flow cytometry was used to measure phagocytic capacity and intracellular $\mathrm{Zn}$ content in both jejunum and caecal tonsils. Additional measures of immune status included intracellular peroxidase and $\mathrm{CD} 3+$ in jejunum and caecal tonsils, respectively. In order to characterise $Z n$ flux during coccidial exposure, transporter expression of ZnT5, ZnT7, ZIP9 and ZIP13 were also measured in both tissues.

\section{Materials and methods}

All procedures of animal care and use for this experiment were approved by the Purdue University Animal Care and Use Committee. Newly hatched, male Ross broiler chicks (708; Aviagen, Inc.) were used for the present study. All chicks were housed in electrically heated battery cages (model no. SB 4 T; Alternative Design Manufacturing) in an environmentally controlled room. Battery cage temperature was maintained at $37 \pm 1^{\circ} \mathrm{C}$ for the first week, and decreased by $3^{\circ} \mathrm{C}$ each consecutive week until $24^{\circ} \mathrm{C}$ in the third week. Chicks were weighed and allocated to groups (six chicks/ cage) in such a way that the initial weight of each group was the same. The chickens were provided ad libitum access to drinking water and feed.

\section{Experimental design}

Expt 1 and 2. In Expt 1, a $3 \times 2$ factorial was utilised with three dietary treatments and two vaccine exposures: (an unchallenged control or ten times the recommended dosage of Coccivac ${ }^{\circledR}-\mathrm{B}(10 \mathrm{CV})$; each treatment was replicated six times. In Expt 2, a $7 \times 2$ factorial was utilised with seven dietary treatments and two vaccine exposures (as in Expt 1); each treatment was replicated six times. Dietary regimens were designed to provide $90 \mathrm{mg}$ of $\mathrm{Zn} / \mathrm{kg}$ of diet from one of two $\mathrm{Zn}$ sources: zinc sulphate $\left(\mathrm{ZnSO}_{4}\right)$ or a $1: 1$ blend of $\mathrm{ZnSO}_{4}$ and Availa ${ }^{\circledR}-\mathrm{Zn} 100$ (Zinpro Corporation). Availa ${ }^{\circledR}$ $\mathrm{Zn} 100(10 \% \mathrm{Zn})$ is a proprietary metal amino acid complex. The Association of American Feed Control Officials describes the product as a complex of a soluble metal salt with an amino acid, where one $\mathrm{Zn}$ ion is bound within an amino acid complex. A basal maize-soyabean meal diet was formulated to provide $\mathrm{Zn}$ from feedstuffs alone and was, on average, $14 \%$ below the National Research Council ${ }^{(39)}$ recommendations, which is $40 \mathrm{mg} / \mathrm{kg}$ for dietary $\mathrm{Zn}$. Ca and non-phytate phosphorus were provided at 9.8 and $4.3 \mathrm{mg} / \mathrm{kg}$, respectively. $\mathrm{Zn}$ provided from the maize-soyabean meal basal diet $(30 \mathrm{mg} / \mathrm{kg}$ of dietary $\mathrm{Zn})$, was taken into account when formulating $\mathrm{Zn}$ premixes, therefore reported inclusion levels are based on total dietary Zn. Expt 1 provided broilers with one of three dietary treatments: basal $(30 \mathrm{mg} / \mathrm{kg}$ of dietary $\mathrm{Zn}$ provided by feedstuffs alone), $90 \mathrm{ZnSO}_{4}(90 \mathrm{mg} / \mathrm{kg}$ of total dietary $\mathrm{Zn}=30 \mathrm{mg} / \mathrm{kg} \mathrm{Zn}$ from basal $+60 \mathrm{mg} / \mathrm{kg}$ supplemental $\mathrm{Zn}$ from $\left.\mathrm{ZnSO}_{4}\right)$, or $90 \mathrm{Blend}(90 \mathrm{mg} / \mathrm{kg}$ of total dietary $\mathrm{Zn}=30 \mathrm{mg} / \mathrm{kg} \quad \mathrm{Zn}$ from basal $+30 \mathrm{mg} / \mathrm{kg}$ supplemental $\mathrm{Zn}$ from $\mathrm{ZnSO}_{4}+30 \mathrm{mg} / \mathrm{kg}$ supplemental $\mathrm{Zn}$ from Availa ${ }^{\circledR}$-Zn 100). Expt 2 introduced additional supplemental $\mathrm{Zn}$ concentration inclusion levels by mixing portions of basal and $90 \mathrm{mg} / \mathrm{kg}$ of $\mathrm{Zn}$ to create intermediate concentrations of 45 and $70 \mathrm{mg} / \mathrm{kg}$ of total dietary $\mathrm{Zn}$.

Coccivac ${ }^{\circledR}$-B (a live oocyst vaccination containing strains of E. acervulina, Eimeria mivati, Eimeria maxima and E. tenella; Intervet, Inc.) administered $10 \mathrm{CV}$ was used as an immune stimulus. The vaccine was introduced to day-old Ross 708 broilers through oral gavage on day 1, 7, 14, and 22 (Expt 1). At 30 and $31 \mathrm{~d}$ of age ( 8 and $9 \mathrm{~d}$ post gavage) one bird per cage from six replicates of each treatment was $\mathrm{CO}_{2}$ asphyxiated, and proximal jejunal sections were removed for fluorophore conjugation and mRNA transcript analysis.

In a nearly identical experimental design, chicks in Expt 2 were orally gavaged at 1, 7, 11, and $17 \mathrm{~d}$ of age. At 26 and $27 \mathrm{~d}$ of age one bird per cage (day 9 and 10 post gavage) was $\mathrm{CO}_{2}$ asphyxiated, and caecal tonsils were removed for fluorophore conjugation and mRNA transcript analysis, as in Expt 1. 
Tissue processing for flow cytometry and transcript analysis

Expt 1. Six jejunal sections $(3 \mathrm{~cm}$ on either side of the midpoint between the bile ducts and the Meckel's diverticulum) per treatment were collected from the broilers, and placed in ice-cold Tris(hydroxymethyl)-aminomethane-glycine buffer (TrisG; Thermo Scientific) before further processing. From each jejunal section, a $1 \mathrm{~cm}$ portion distal to the Meckel's diverticulum was placed into Trizol ${ }^{\circledR}$ (Life Technologies) for later transcript analysis. Jejunal sections were cut longitudinally and disrupted with a sterile cell sieve (CD-1 ${ }^{\text {TM }}$, 60 mesh screen $230 \mu \mathrm{m}$ pore size; Sigma-Aldrich). Phosphate-free buffer, i.e. TrisG, was used to minimise $\mathrm{Zn}$ chelation during tissue processing ${ }^{(40)}$. Cell homogenates were centrifuged at $800 \mathrm{~g}$ for $20 \mathrm{~min}$, and the supernatant was decanted. The supernatant was centrifuged at $3560 \mathrm{~g}$ for $20 \mathrm{~min}$; the pellet was retained and re-suspended in $2 \mathrm{ml}$ of TrisG. The crude cell suspension was then incubated for $30 \mathrm{~min}$ at $37^{\circ} \mathrm{C}$. Five hundred $\mu \mathrm{l}$ of each cell suspension was divided into four reagent tubes: an unlabelled tube (to determine background fluorescence) and three separate reagent tubes containing fluorescently conjugated cells. Fluorescent indicators included: $12.5 \mu \mathrm{l}$ of FluoSpheres ${ }^{\circledR}$ (1.0 $\mu \mathrm{m}$ diameter; Invitrogen) for measurement of phagocytic activity ${ }^{(41)} ; 100 \mu \mathrm{l}$ of dihydrorhodamine-123 to report the presence of $\mathrm{H}_{2} \mathrm{O}_{2}$ and intracellular peroxidase ${ }^{(42)} ; 10 \mu \mathrm{l}$ of Newport Green ${ }^{\mathrm{TM}}$ DCF diacetate (Invitrogen) for determination of intracellular $\mathrm{Zn}$ levels ${ }^{(43)}$. A typical avian phagocyte ranges between 8 and $10 \mu \mathrm{m}^{(44)}$. The $1.0 \mu \mathrm{m}$ diameter of carboxylate-modified microspheres was thought to be of adequate size to stimulate phagocytic response, yet small enough to allow for mechanical phagocytosis to occur ${ }^{(45)}$. All tubes underwent a final incubation for $30 \mathrm{~min}$ at $37^{\circ} \mathrm{C}$. After incubation, cells were washed using a final $10 \mathrm{~min} 3000 \mathrm{~g}$ spin. The supernatant was discarded and the pellet was re-suspended in $1 \mathrm{ml}$ TrisG. Cells were preserved with $500 \mu \mathrm{l}$ of $2 \%$ paraformaldehyde in Hanks' balanced salt solution (no $\mathrm{Ca}$, no $\mathrm{Mg}$; Life Technologies), and were stored at $3^{\circ} \mathrm{C}$ for next day analysis. Percent positive cells were calculated by bird, as the difference in fluorescence between cells only and fluorescently conjugated cells. Median fluorescent intensity (MFI) of fluorescently conjugated cells was also determined.

Expt 2. Tissue processing for Expt 2 was nearly identical to the protocol described in Expt 1; therefore, only the differences between the two experiments are described in this section. Caecal tonsils from six birds per treatment were collected. One caecal tonsil went into Trizol ${ }^{\circledR}$ for later transcript analysis. The remaining tonsils were processed for flow cytometry. Caecal tonsil cells are more lymphoid in nature than jejunal cells, and were therefore centrifuged at lower speeds: $500 \boldsymbol{g}$ for $20 \mathrm{~min}$. The supernatant was decanted and centrifuged at $1150 \mathrm{~g}$ for $20 \mathrm{~min}$; the pellet was retained and re-suspended in $2 \mathrm{ml}$ of TrisG. The crude cell suspension was then incubated for $30 \mathrm{~min}$ at $37^{\circ} \mathrm{C}$. Five hundred $\mu \mathrm{l}$ of each cell suspension was divided into four reagent tubes: one unlabelled (to determine background fluorescence) and three separate reagent tubes (fluorescently conjugated cells).
Fluorescent indicators included: $12.5 \mu \mathrm{l}$ of FluoSpheres ${ }^{\circledR}$ (1.0 $\mu \mathrm{m}$ diameter; Invitrogen) for measurement of phagocytic activity $^{(41)} ; 5 \mu \mathrm{l}$ of mouse anti-chicken CD3+-fluorescein isothiocyanate (FITC) conjugate to label the T cell receptorassociated CD3 complex (SouthernBiochem); $10 \mu$ l of Newport Green $^{\mathrm{TM}}$ DCF diacetate (Invitrogen) for determination of intracellular $\mathrm{Zn}$ levels ${ }^{(43)}$. Caecal tonsil cells were preserved in $2 \%$ paraformaldehyde and refrigerated $\left(3^{\circ} \mathrm{C}\right)$ for next day analysis.

\section{Flow cytometry parameters and data analysis}

Expt 1 and 2 utilised a benchtop flow cytometer with 3-blue and 1-red lasers configured for excitation at 488 and $640 \mathrm{~nm}$, respectively (C6 BD Accuri Cytometer, Inc.). The FL1 optical filter with emission detection of $522 / 30 \mathrm{~nm}$ was used for Newport Green $^{\mathrm{TM}}$, CD3+-FITC, and dihydrorhodamine-123 analysis. The FL2 optical filter with emission at 585/40 nm was used to detect phagocytic microbeads. Data were collected on 20000 cells per sample. Total cell population was examined on a scatter-height (FSC-H) $v$. side scatter-height (SSC-H) plot. Histogram overlays were generated using System II Software (Beckman Coulter Company). Histograms of optical filter by cell count were generated for cells-only and each measured fluorophore. For each bird, a fluorescently labelled cell population was overlaid against the unlabelled cells-only histogram. The shift in cell population between fluorescently conjugated cells and cells-only was calculated as percentage fluorescence difference. Fluorescence of cellsonly and fluorophore-labelled cells were used to estimate MFI of FCS-generated histograms.

\section{Gene expression analysis}

Trizol ${ }^{\circledR}$ was used to extract total RNA from jejunal and/or caecal tonsil mucosa according to manufacturer's instructions. RNA samples were dissolved in nuclease-free $\mathrm{H}_{2} \mathrm{O}$, and concentration was determined with a Nanodrop reader (Thermo Scientific). DNA was enzymatically degraded from RNA samples, using the TURBO DNA-free ${ }^{\mathrm{TM}}$ kit (Applied Biosystems). RNA samples underwent gel electrophoresis on $0.8 \%$ agarose gel in $1 \times$ Tris-acetate EDTA running buffer to check for integrity and genomic DNA contamination. Expression of ZnT genes was assessed through RT-PCR. Primers for G. gallus-specific ZnT5, ZnT7, ZIP9, and ZIP13 solute carriers were designed from provisional mRNA sequences from NCBI (http://www.ncbi.nlm.nih.gov). Each primer pair was designed to be at least $20 \mathrm{bp}$ in length. The University of California, Santa Cruz (UCSC) database was used to blast primer pairs back to the chicken genome (http://genome.ucsc.edu). Primer pairs crossed an intron/ exon boundary, and matched the target template sequence. Primer sequences, annealing temperatures and efficiencies are listed in Table 1. RNA samples were reverse transcribed using the MultiScribe ${ }^{\mathrm{TM}}$ reverse transcriptase kit (Applied Biosystems). PCR was performed using the Bio-Rad iCycler (BioRad). The PCR mix was composed of $0.5 \mu \mathrm{g}$ of complementary DNA(cDNA), $0.075 \mathrm{nmol}$ of each forward and reverse primer, and iQ SYBR green master mix (BioRad). 
Table 1. Primer pairs selected for zinc trafficking

\begin{tabular}{|c|c|c|c|c|}
\hline & Forward primer & Reverse primer & Annealing temperature $\left({ }^{\circ} \mathrm{C}\right)$ & Efficiency (\%) \\
\hline ZnT5 & 5'-GGACATTCCCATGTGTCCTC-3' & 5'-AGAGCAGAGGGGATCAGCTA-3' & $62 \cdot 5$ & 99.5 \\
\hline ZnT7 & 5'-ATTTTGATGCAGCGAACTCC-3' & 5'-АTCСАССТTССАТСАGСАTC-3' & $52 \cdot 9$ & 105 \\
\hline Zip9 & 5'-CATTGGCAGCACCTGTTATG-3' & $5^{\prime}$-CGCGATTCCTCCTACTTCTG-3' & 59.5 & 100 \\
\hline Zip13 & 5'-AGCTTTGCAATTGGTGGACT-3' & 5'-GGGCACTCCTCCTCTTCTTT--3' & $59 \cdot 5$ & 110 \\
\hline HPRT1 & $5^{\prime}$-TGCAGACGATCTGGAGAAAG- $3^{\prime}$ & 5'-TGGGGATTGACTTGTCACTGT-3' & 59.5 & 107 \\
\hline TBP & 5'-AAGCGACACAGGGAACATCT-3' & $5^{\prime}$-AACCAAGATTCACCGTGGAC- $3^{\prime}$ & 62.5 & 107 \\
\hline
\end{tabular}

ZnT5, Zn efflux transporter 5; ZnT7, Zn efflux transporter 7; Zip9, Zn influx transporter 9; Zip13, Zn influx transporter 13; HPRT1, hypoxanthine phosphoribosyltransferase 1; TBP, TATA-binding protein.

Nuclease-free $\mathrm{H} 2 \mathrm{O}$ was added for total reaction volumes of $25 \mu \mathrm{l}$. Reactions were initiated with a $5 \mathrm{~min}, 95^{\circ} \mathrm{C}$ incubation. Post incubation, reactions were cycled forty times using the following procedure: $10 \mathrm{~s}$ at $95^{\circ} \mathrm{C}, 20 \mathrm{~s}$ at primer-specific annealing temperature, $72^{\circ} \mathrm{C}$. The Pfaffl method ${ }^{(46)}$ was used for the relative quantification of real-time RT-PCR. The initial housekeeping gene, glyceraldehyde 3-phosphate dehydrogenase $(G A P D H)$, was found to be significantly affected by exposure to coccidial vaccine. Due to the inconsistency of housekeeping gene expression, the BestKeeper-Excel-based tool was used to evaluate potential genes and create an expression standard ${ }^{(47)}$. Pair-wise correlation analysis of all pairs of candidate genes revealed that both hypoxanthine phosphoribosyltransferase 1 (HPRT1) and TATA-binding protein $(T B P)$ had the lowest between-sample variations, and high correlations with the BestKeeper index. The geometric mean of these two genes was used to normalise target gene expression.

\section{Statistical analyses}

All data were analysed using the PROC MIXED procedures of SAS ${ }^{\circledR}$ (SAS Institute, 2012) as a completely randomised design. Cage was the experimental unit for all experiments discussed. For Expt 1, a $3 \times 2$ factorial was utilised, with three dietary regimens (maize-soyabean meal basal, $90 \mathrm{mg} / \mathrm{kg}$ dietary $\mathrm{Zn}$ from $\mathrm{ZnSO}_{4}$, or $90 \mathrm{mg} / \mathrm{kg}$ dietary $\mathrm{Zn}$ from a 1:1 blended source of Availa ${ }^{\circledR}-\mathrm{Zn}$ and $\mathrm{ZnSO}_{4}$ ), and two vaccine exposures (an unchallenged control or a 10CV). Each treatment was replicated six times. For Expt 2 , a $7 \times 2$ factorial was utilised with seven dietary regimens (maize-soyabean meal basal, 45, 70 and $90 \mathrm{mg} / \mathrm{kg}$ dietary $\mathrm{Zn}$ from $\mathrm{ZnSO}_{4}$, or Blend). Treatment comparisons were obtained through Tukey-Kramer means separation, and significance was established at $P \leq 0 \cdot 05$.

\section{Results}

\section{Mucosal response}

Jejunum. Flow cytometry was used to characterise mucosal response to $10 \mathrm{CV}$ and dietary $\mathrm{Zn}$ source. There was no significant interaction between challenge and $\mathrm{Zn}$ treatment in any of the measured jejunal mucosal parameters. The data is expressed as both percentage of cells positive for fluorophore and the MFI of the fluorophore positive population. Unlabelled cells, from individual birds, were used to account for background fluorescence in each measurement. Exposure to $10 \mathrm{CV}$ decreased phagocytic capacity in jejunal cells by $2 \%$, with no change in MFI (Fig. 1(a) and (b)). In order to further characterise the mucosal response to $10 \mathrm{CV}$, dihydrorhodamine-123 was included to measure peroxynitrite (a reactive oxygen intermediate) produced by phagocytic cells during oxidative burst. Repeated exposure to 10CV had no significant impact on percentage positive or MFI (Fig. 1(c) and (d)). Intracellular-free $\mathrm{Zn}$ was highly variable between birds, and therefore was not significantly different with $10 \mathrm{CV}$ (Fig. 1(e) and (f)). Dietary regimen did not impact any of the measured flow parameters for jejunal tissue.

Caecal tonsils. In contrast to jejunal cells, a significant interaction occurred between $10 \mathrm{CV}$ and $\mathrm{Zn}$ treatment in caecal tonsil cells $(P<0 \cdot 0001)$, with no significant change in MFI (Fig. 2(a) and (b)). While the main effect mean of $\mathrm{Zn}$ treatment was not significant $(P=0 \cdot 1), 10 \mathrm{CV}$ had a significant impact on phagocytic capacity $(P=0 \cdot 001)$. This interaction indicates that the phagocytic capacity of caecal cells significantly increased with the $10 \mathrm{CV}$, with the magnitude of increase being more pronounced with higher levels of $\mathrm{Zn}$ (70 and $90 \mathrm{mg} / \mathrm{kg}$, regardless of source). The possibility of a shift in cell population was investigated with a fluorophore, designed to conjugate to the T-cell specific $(\mathrm{CD} 3+)$ receptors. There was no significant effect of $10 \mathrm{CV}$ on percentage of cells positive for $\mathrm{CD} 3+$ conjugation; however, the MFI of $\mathrm{CD} 3+$ was reduced by $94 \%(P=0 \cdot 001)$ with $10 \mathrm{CV}$ (Fig. 2(c) and (d)). The percentage of caecal cells positive for Newport Green $^{\text {TM }}$ decreased by an average of $27 \%$ with $10 \mathrm{CV}$ $(P<0.0001)$. This reduction in percentage positive was coupled with an $86 \%$ decrease $(P<0 \cdot 0001)$ in MFI (Fig. 2(e) and (f)). As with jejunal cells, $\mathrm{Zn}$ treatment had no effect on the measured flow parameters.

\section{Zinc trafficking}

Jejunum. A significant interaction between dietary regimen and $10 \mathrm{CV}$ occurred in Zip13 expression (Fig. 3). Jejunal tissue from birds consuming $90 \mathrm{ZnSO}_{4}$ had a 4 -fold increase in Zip13 expression with exposure to coccivac. Zip9 expression was not altered by $10 \mathrm{CV}$. Compared to control tissues, $10 \mathrm{CV}$ reduced $\mathrm{ZnT7}$ expression $(P=0.02)$ by $50 \%$. The ratio of Zip:ZnT mRNA was increased by $75 \%$ with $10 \mathrm{CV}$ (Fig. 5). With the exception of Zip13, dietary Zn treatment did not impact transporter expression.

Caecal tonsil. A significant interaction between dietary regimen and vaccine exposure occurred in Zip13 expression 
(a)

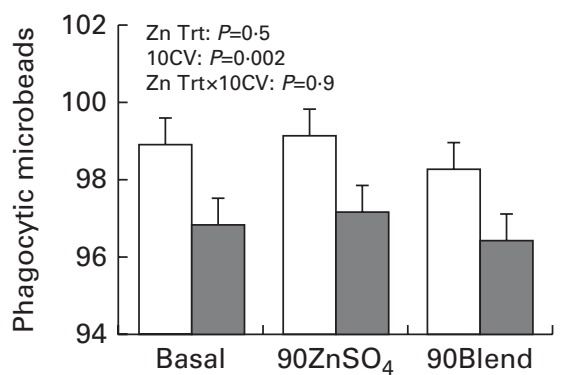

(c)

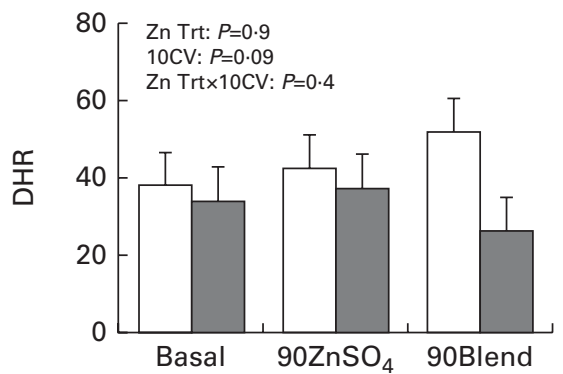

(e)

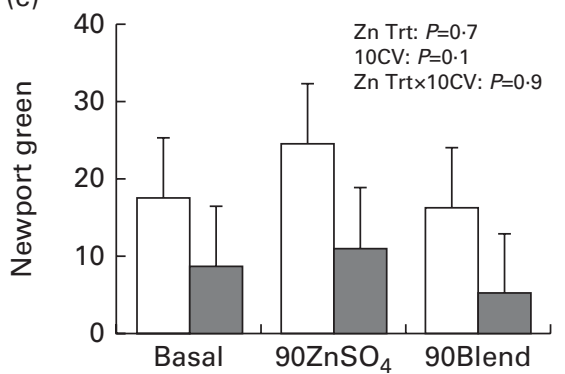

(b)

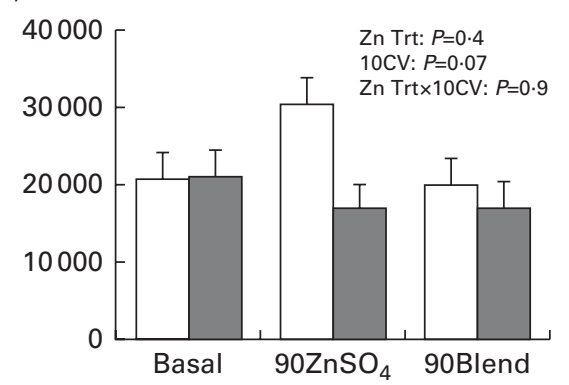

(d)

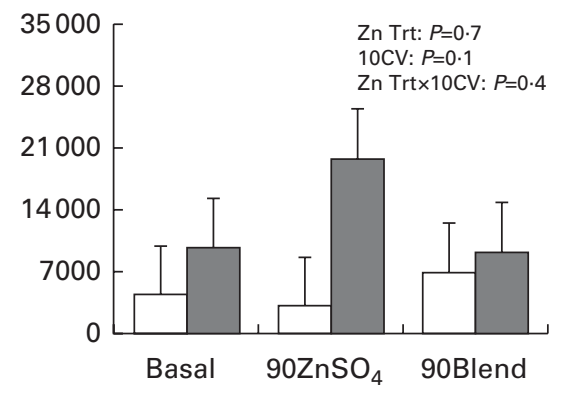

(f)

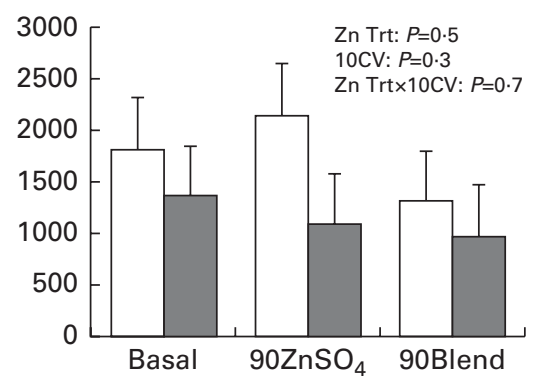

Fig. 1. Jejunal mucosal response. The percentage of jejunal cells positive for the measured fluorophore (a, c and e) and median histogram fluorescent intensity of the cell population (b, $d$ and f). Expt 1 labels include FluoSphere ${ }^{\mathrm{TM}}$ microbeads to measure percentage of cells positive (a) and median fluorescent intensity (MFI) (b) of phagocytic microbeads. Dihydrorhodamine-123 (DHR) was used to report the presence of $\mathrm{H}_{2} \mathrm{O}_{2}$ and intracellular peroxidase, expressed as both percent cells positive (c) and MFI (d). Newport Green ${ }^{\mathrm{TM}}$ indicator measured intracellular zinc content again expressed as both percent of cells positive for the Newport Green $^{\mathrm{TM}}$ indicator (e) and the median shift in fluorescent intensity (f). Values represent mean response of six birds per zinc source for both control (Con) and $10 \mathrm{CV}\left(10 \times\right.$ dose of coccidial vaccine Coccivac $\left.{ }^{\circledR}-\mathrm{B}\right)$ birds. Significant $(P \leq 0.05)$ main effect mean comparisons of zinc source, $10 \mathrm{CV}$, and their interactions are indicated within each panel. Dietary regimens consisted of a basal maize-soyabean meal diet, or basal diet supplemented with either zinc from zinc sulphate $\left(\mathrm{ZnSO}_{4}\right)$, or a blended source (1:1 blend of $\mathrm{ZnSO}_{4}$ and Availa $\left.{ }^{\circledR}-\mathrm{Zn}\right)$ to achieve $90 \mathrm{mg} / \mathrm{kg}$ of total dietary zinc. Birds were unchallenged (Con, $\left.\square\right)$, or exposed to $10 \mathrm{CV}(\square)$ on days $1,7,14$, and 22 , and the final gavage occurred $10 \mathrm{~d}$ before tissue collection. Trt, treatment.

(Fig. 4). In contrast to jejunal tissue where $90 \mathrm{ZnSO}_{4}$ maximised Zip13 expression, birds consuming the 90Blend treatment had a 27-fold increase in Zip13 caecal tonsil expression. Zip9 expression within caecal tonsil cells was increased 2-fold with 10CV. Caecal ZnT expression was not significantly impacted by Zn treatment or 10CV (Fig. 4). The ratio of Zip:ZnT mRNA was increased 16-fold with $10 \mathrm{CV}$ (Fig. 5). As in the jejunum, Zip13 expression was the only measured transporter impacted by dietary $\mathrm{Zn}$ source.

\section{Discussion}

\section{Mucosal response of jejunal and caecal tonsil tissues}

It is known that repeated exposure to oocysts results in increased cellular infiltration, and faster resolution of infection $^{(48,49)}$. In the present study, repeated coccivac exposure within the jejunum decreased the phagocytic population.
Respiratory burst, a process through which bactericidal superoxide and peroxides are produced, is the primary mechanism through which phagocytes induce lysis ${ }^{(50)}$. In Expt 1, there was no effect of $\mathrm{Zn}$ source or challenge on dihydrorhodamine-123 signal (Fig. 1(c) and (d)). In poultry, secondary coccidial infections are characterised by high concentrations of CD8 $+\mathrm{T}$ cells within intraepithelial cell infiltrates ${ }^{(51-54)}$. During the course of infection, $\mathrm{T}$ cells produce interferon- $\gamma$, a cytokine which recruits leukocytes and enhances the lysosomal activity of macrophages. Laurent et al. ${ }^{(49)}$ found that transcript levels of interferon- $\gamma$ peaked $7 \mathrm{~d}$ post infection and returned to baseline levels $13 \mathrm{~d}$ post-infection. In the present study, tissues were repeatedly exposed to coccivac and collected on day 8 and 9 post gavage. Therefore, in Expt 1, the innate macrophage response may have given way to an adaptive cellular immune response by the time of collection. Jejunal intracellular Zn, measured by Newport Green ${ }^{\mathrm{TM}}$, was 
(a)

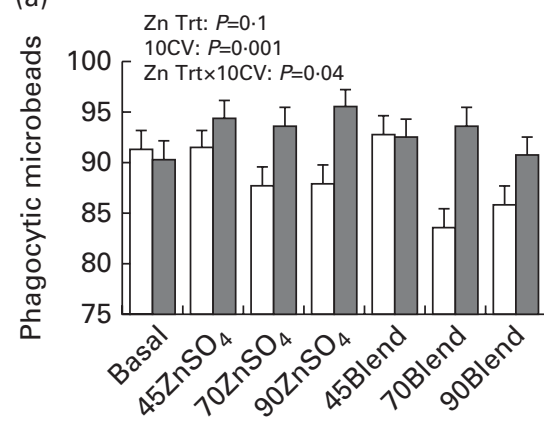

(c)

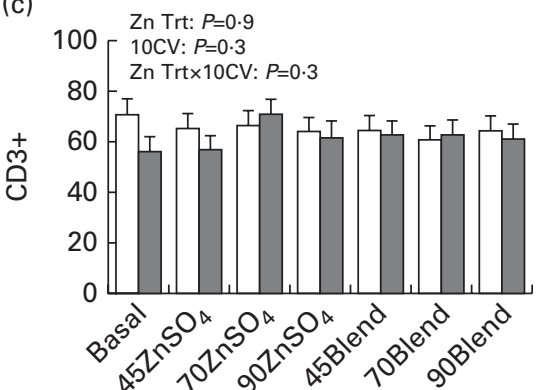

(e) Zn Trt: $P=0.4$ 10CV: $P=0.0001$

100 Zn Trt×10CV: $P=0.8$

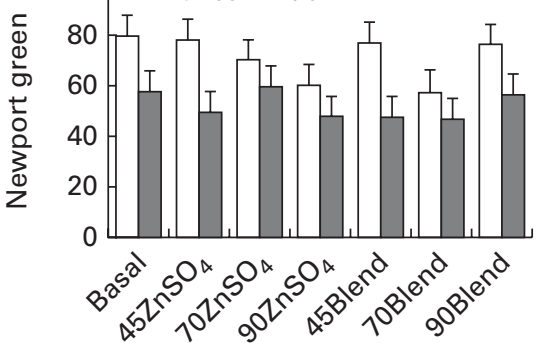

(b)

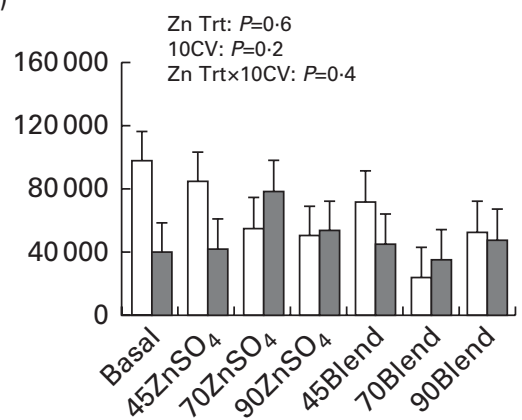

(d)

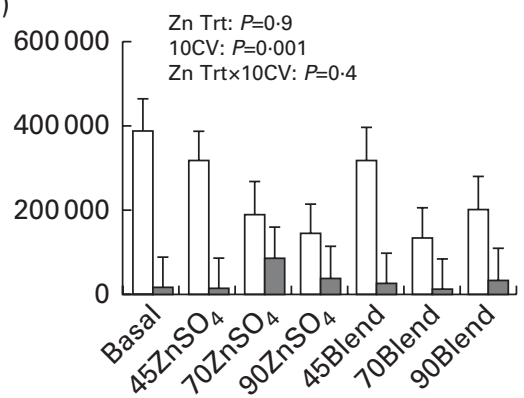

(f)

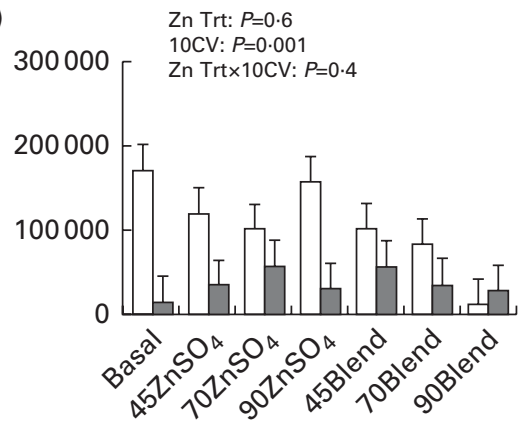

Fig. 2. Caecal tonsil mucosal response. The percentage of caecal tonsil cells positive for the measured fluorophore (a, $c$ and e) and median histogram fluorescent intensity of the cell population (b, $d$ and f). Expt 2 labels include FluoSphere ${ }^{\mathrm{TM}}$ microbeads to measure percentage of cells positive (a) and median fluorescent intensity (MFI) (b) of phagocytic microbeads. Mouse-anti-chicken CD3+-fluorescein isothiocyanate (FITC) conjugate, used to label the CD3 $+\mathrm{T}$ cell receptor complex, is expressed as both percent cells positive (c) and MFI (d). Newport Green ${ }^{\mathrm{TM}}$ indicator measured intracellular zinc content again expressed as both percent of cells positive for the Newport Green ${ }^{\mathrm{TM}}$ indicator (e) and the median shift in fluorescent intensity (f). Values represent mean response of six birds per zinc regimen for both control (Con) and 10CV (10x dose of coccidial vaccine Coccivac $\left.{ }^{\circledR}-\mathrm{B}\right)$ birds. Significant $(P \leq 0.05)$ main effect mean comparisons of zinc regimen, $10 \mathrm{CV}$, and their interactions are indicated within each panel. Dietary regimens consisted of a basal maize-soyabean meal diet, or basal diet supplemented with either zinc from zinc sulphate $\left(\mathrm{ZnSO}_{4}\right)$, or a blended source (1:1 blend of $\mathrm{ZnSO}_{4}$ and Availa $\left.{ }^{\circledR}-\mathrm{Zn}\right)$ to achieve 45,70 , or $90 \mathrm{mg} / \mathrm{kg}$ of total dietary zinc. Birds were unchallenged (Con, $\square$ ), or exposed to $10 \mathrm{CV}(\square)$ on days $1,7,11$, and 17 , with the final gavage occurring $10 \mathrm{~d}$ before tissue collection. Trt, treatment.

widely variable between birds, and therefore the drop in intracellular $\mathrm{Zn}$ with $10 \mathrm{CV}$ was not significant. However, other studies have reported decreases in intracellular $\mathrm{Zn}$ with infection ${ }^{(55,56)}$; it is said that the drop in intracellular $\mathrm{Zn}$ acts as a protective mechanism through the induction of apoptosis. Thambiayya et al. ${ }^{(56)}$ found that $\mathrm{Zn}$ binding can inhibit caspase 3, a pro-apoptotic protein. Limiting labile $\mathrm{Zn}$ within the cell may release inhibition of caspase 3 and promote apoptosis during oxidative stress.

Caecal tonsil cells (Expt 2) expressed a significant interaction between $\mathrm{Zn}$ treatment and $10 \mathrm{CV}$. Exposure to coccidia (10CV) increased phagocytic capacity; however, the magnitude of increase from unchallenged and challenged groups was more pronounced with 70 and $90 \mathrm{mg} / \mathrm{kg}$ of supplemental Zn. Dubben et al. ${ }^{(57)}$ found that chelating Zn out of solution was found to enhance monocyte (modelled using the HL-60 cell line) differentiation and phagocytic potential. Therefore, if $\mathrm{Zn}$ has a negative impact on monocyte differentiation, results of Expt 2 may reflect lower steady state monocyte activity within caecal tonsils. This steady state population of monocytes did not negatively impact the phagocytic capabilities of 10CV. Furthermore, caecal tonsils are known to contain a high concentration of macrophages; macrophage inflammatory protein (a macrophage recruiting chemokine) was upregulated 80 -fold in E. tenella-infected caecal cells ${ }^{(49)}$. Laurent et $a l .{ }^{(49)}$ found that the upregulation of inflammatory cytokine expression was similar between E. tenella-infected caecal tonsils and E. maxima-infected jejunum; however, the caecal response was more pronounced. Several studies have noted that poultry have an increased cellular immune 

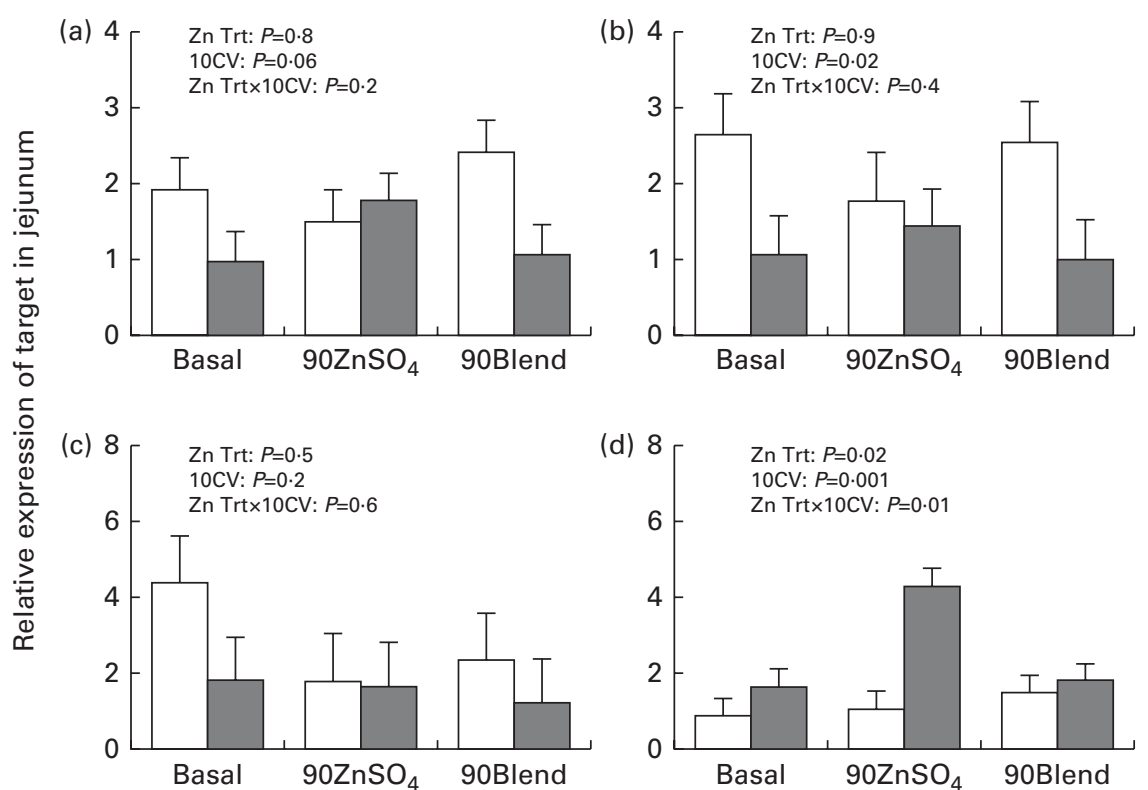

Fig. 3. Jejunal zinc transporter expression. (a) ZnT5, (b) ZnT7, (c) ZIP9 and (d) ZIP13. Zinc transporter expressions in jejunal mucosal (Expt 1) from 30 and 31 d-old broilers consuming different dietary zinc sources and exposed to $10 \times$ dose of coccidial vaccine Coccivac ${ }^{\circledR}-\mathrm{B}$ (10CV). Values represent mean response of six birds per zinc source for both control (Con) and 10CV birds. Significant $(P \leq 0.05)$ main effect mean comparisons of zinc source, 10CV, and their interactions are indicated within each panel. Dietary regimens consisted of a basal maize-soyabean meal diet, or basal diet supplemented with either zinc from zinc sulphate $\left(\mathrm{ZnSO}_{4}\right)$, or a blended source (1:1 blend of $\mathrm{ZnSO}_{4}$ and Availa ${ }^{\circledR}-\mathrm{Zn}$ ) to achieve $90 \mathrm{mg} / \mathrm{kg}$ of total dietary zinc. Birds were unchallenged (Con, $\square$ ), or exposed to $10 \mathrm{CV}$ ( $\square$ ) on days 1 , 7,14 , and 22, and the final gavage occurred $10 \mathrm{~d}$ before tissue collection. Figure depicts the expression of the target genes against the geometric mean of two housekeeper genes hypoxanthine phosphoribosyltransferase 1 (HPRT1) and TATA-binding protein (TBP) as selected by the BestKeeper index ${ }^{(47)}$. Trt, treatment.

response (systemically and within the small intestine and caecal tonsils) to coccidial infection ${ }^{(48,49,51-53)}$. Given the importance of the cellular immune response during coccidial infection $^{(51-60)}$, we chose to focus on $\mathrm{CD} 3+$ expression in caecal tonsils. Though we found no change in the population of cells positive for $\mathrm{CD} 3+$, there was a significant reduction in the MFI. The CD3+ marker is a critical inducer of the signalling cascade necessary to activate $\mathrm{T}$ cells. In human

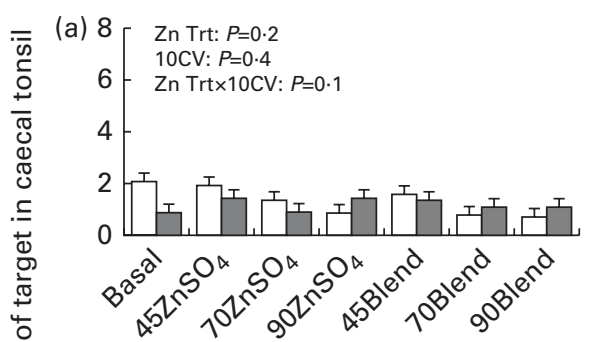

(b) 8 Zn Trt: $P=0 \cdot 6$
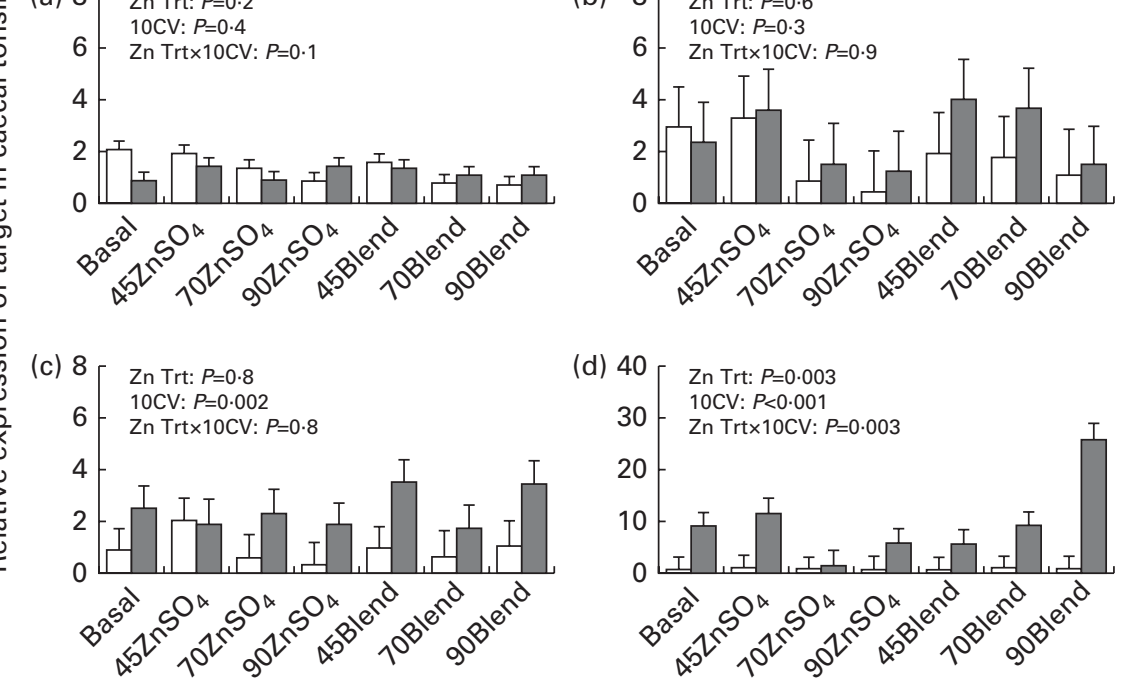

Fig. 4. Caecal tonsil zinc transporter expression. (a) ZnT5, (b) ZnT7, (c) ZIP9 and (d) ZIP13. Zinc transporter expressions in caecal tonsil mucosa (Expt 2) from 26 and $27 \mathrm{~d}$-old broilers consuming different dietary zinc sources and exposed to $10 \times$ dose of coccidial vaccine Coccivac ${ }^{\circledR}$-B (10CV). Values represent mean response of six birds per zinc source for both control (Con) and 10CV birds. Significant $(P \leq 0.05)$ main effect mean comparisons of zinc source, 10CV, and their interactions are indicated within each panel. Dietary regimens consisted of a basal maize-soyabean meal diet, or basal diet supplemented with either zinc from zinc sulphate $\left(\mathrm{ZnSO}_{4}\right)$, or a blended source (1:1 blend of $\mathrm{ZnSO}_{4}$ and Availa ${ }^{\circledR} \mathrm{Zn}$ ) to achieve 45 , 70 , or $90 \mathrm{mg} / \mathrm{kg}$ of total dietary zinc. Birds were unchallenged (Con, $\square$ ), or exposed to $10 \mathrm{CV}(\square)$ on days $1,7,11$, and 17, with the final gavage occurring $10 \mathrm{~d}$ before tissue collection. Figure depicts the expression of the target genes against the geometric mean of two housekeeper genes hypoxanthine phosphoribosyltransferase 1 (HPRT1) and TATA-binding protein (TBP) as selected by the BestKeeper index ${ }^{(47)}$. Trt, treatment. 


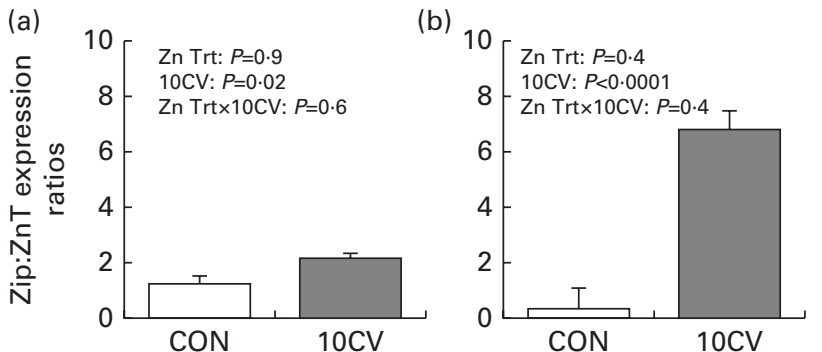

Fig. 5. Ratio of zinc influx transporter (Zip):zinc efflux transporter (ZnT) expression. Zip:ZnT expression in jejunal (a) and caecal (b) cells. Mean values with their standard errors represent ratios which were calculated from expression data, by cage as: (Zip9 + Zip13)/(ZnT5 + ZnT7). The main effects of dietary treatment (Expt 1 (a) basal maize-soyabean meal diet, or basal diet supplemented with either $\mathrm{Zn}$ from zinc sulphate $\left(\mathrm{ZnSO}_{4}\right)$, or a blended source, $1: 1$ blend of $\mathrm{ZnSO}_{4}$ and Availa ${ }^{\circledR}-\mathrm{Zn}$, to achieve $90 \mathrm{mg} / \mathrm{kg}$ of total dietary $\mathrm{Zn}$. Expt 2 (b) was nearly identical with the exception of two additional supplemental levels at 45 and $70 \mathrm{mg} / \mathrm{kg}$ dietary $\mathrm{Zn}$ ), and vaccine exposure (unchallenged control (CON), or $10 \mathrm{CV}(10 \times$ dose of coccidial vaccine Coccivac $\left.{ }^{\circledR}-\mathrm{B}\right)$ ) were analysed. Vaccine exposure (10CV) had a significant effect on Zip:ZnT expression ratio and $P$ values are indicated within each panel. Trt, treatment.

$\mathrm{T}$ cell lines, the $\mathrm{CD} 3+$ marker becomes internalised and eventually degraded, resulting in a loss of CD3 + signal $^{(61,62)}$. This mechanism is similar in chickens, as the $\mathrm{T}$ cell receptor/ CD3 complex is known to contain an internalisation motif ${ }^{(63)}$. Furthermore, Göbel \& Dangy ${ }^{(63)}$ determined that CD3 was downregulated in $\alpha \beta$ T cells during stimulation. Therefore, while the results of the present study reflect no change in total $\mathrm{T}$ cell population, they do suggest an increase in activated $\mathrm{T}$ cells within $10 \mathrm{CV}$ caecal tonsils. Caecal tonsils are the largest lymphoid organ in the chicken, and they can function in a manner similar to that of mammalian Peyer's patches ${ }^{(64)}$. Histologically, caecal tonsils contain germinal centres and IgA-positive B cells, which survey the intestinal immune environment, and aid in the development of intestinal immunity $^{(65)}$. The jejunum also contains a large amount of lymphocytes within the epithelium and lamina propria ${ }^{(64)}$. However, between the two organs, caecal tonsils contain twice the amount of lymphocytes as the jejunum does ${ }^{(66)}$. Therefore, the difference in phagocytosis between jejunum and caecal tonsils may lie in the variability of cell type within those organs. The amount of free $\mathrm{Zn}$ (Newport Green ${ }^{\mathrm{TM}}$ ) within caecal tonsils was significantly decreased with $10 \mathrm{CV}$. The decrease of free $\mathrm{Zn}$ within caecal tonsil cells is presumably a protective mechanism, promoting apoptosis and limiting tissue damage.

\section{Zinc trafficking within jejunum and caecal tonsils}

ZnT measured in Expt 1 and 2 are localised to the endoplasmic reticulum/Golgi complex but expressed different directionality of transport ${ }^{(19,20)}$. In mammals, ZnT5 and ZnT7 are specifically thought to transport $\mathrm{Zn}$ from the cytosol to the Golgi, while ZIP9 and ZIP13 are responsible for vesicular Zn influx into the cytoplasm ${ }^{(24-27)}$. In Expt 1, Zip13 mRNA was significantly upregulated in the $90 \mathrm{ZnSO}_{4}$ treatment in the jejunum during challenge, but not by the 90Blend treatment. This finding suggests differences in availability between $\mathrm{Zn}$ sources $^{(67)}$. ZnT7 expression in Expt 1 jejunum, was significantly decreased with $10 \mathrm{CV}$. This is in contrast to liver expression where ZnT5 and ZnT7 have been shown to increase with inflammation induced by lipopolysaccharide ${ }^{(32)}$. Upregulation of Zip transporters coupled with decreased ZnT expression suggests that trafficking from cytosolic compartments to the Golgi was decreased with exposure to $10 \mathrm{CV}$. However, these responses are tissue-specific, and the intestine is known to have a unique $\mathrm{ZnT}$ response during inflammation. Guthrie et al. ${ }^{(68)}$ noted degradation of ZIP14 with lipopolysaccharide (as opposed to the upregulation noted in liver); it was hypothesised that highly challenging immunoenvironment was responsible for the differential responses between the jejunum and liver. In keeping with the general downregulation of ZnT during coccidial challenge, a recent report noted a significant decrease in the expression of ZnT1 with Eimeria infection $^{(69)}$. A decrease in ZnT1 along with the finding of the present study of a decrease in jejunal ZnT7 would suggest that cells do limit Zn efflux into intracellular compartments ${ }^{(69)}$. This conclusion is strengthened by the observed trend of decreased free intracellular $\mathrm{Zn}$ in the present study (as measured by Newport Green ${ }^{\mathrm{TM}}$ ). This indicates that within the jejunum, movement of $\mathrm{Zn}$ into the cytoplasm was upregulated during repeated exposure to coccidial vaccine (10CV).

Caecal tonsils followed a similar pattern. In comparison to the jejunum, 10CV appeared to have little impact on measured ZnT mRNA expression in caecal tonsils. Thus, very little has been reported on ZnT expression within caecal tonsils. Though the expression of measured ZnT was not downregulated with $10 \mathrm{CV}$, the expression of both Zip9 and Zip13 were significantly upregulated. In contrast to jejunal cells, the greatest expression of Zip13 was observed in 90Blend treatment.

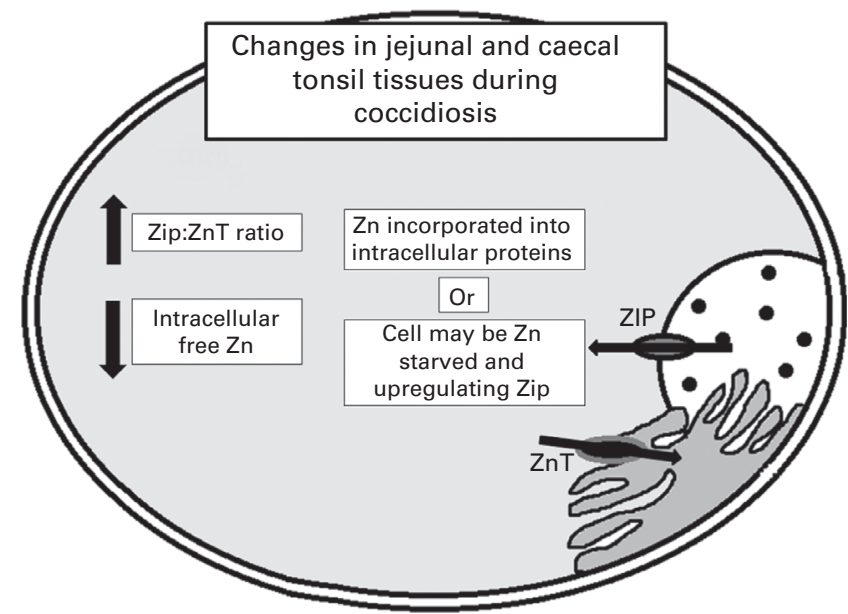

Fig. 6. Model of intracellular zinc trafficking during repeated exposure to coccidial vaccine. Amended mechanism for zinc transporter expression. Coccidiosis had a larger impact on transporter expression than dietary zinc regimen. Zinc influx transporter (Zip):zinc efflux transporter (ZnT) ratio increased with challenge in jejunal cells and caecal tonsils. However, flow cytometry reported a decrease in intracellular-free zinc with challenge. The upregulation of Zip transporters coupled with lower intracellular-free zinc suggests that the cell (1) may have shuttled zinc into cytosolic proteins during coccidial challenge, or (2) upregulated Zip transporters in an effort to replenish lost cytosolic zinc. 
To our knowledge this is the first report that has linked the expression of ZnT to a dietary $\mathrm{Zn}$ source. Star et al. ${ }^{(67)}$ found that the bioavailability of Availa ${ }^{\circledR}-\mathrm{Zn}$, as measured through broiler chick Zn tibia content, was higher than that of $\mathrm{ZnSO}_{4}$. Castillo et al. ${ }^{(70)}$ reported the use of an organic Zn source tended to reduce enterobacteria levels in weanling pig jejunums. It is therefore possible that the observed changes in Zip13 expression in Expt 1 and 2 were due to altered bioavailability and/or altered microbial load. Overall, our data shows that the ratio of Zip:ZnT expression was significantly increased due to $10 \mathrm{CV}$ (Fig. 5). This suggests movement of $\mathrm{Zn}$ from intracellular compartments to the cytoplasm. As Newport Green ${ }^{\mathrm{TM}}$ only measures free, not bound, $\mathrm{Zn}$, this increase in Zip:ZnT ratio suggests that $\mathrm{Zn}$ may be incorporated into cytosolic proteins (e.g. MT or other metalregulatory protein). Our hypothesis is that cells upregulate ZIP transporters in an effort to promote cell/tissue protective processes during coccivac exposure, i.e. apoptosis. However, this does not exclude the possibility that cells are simply $\mathrm{Zn}$ starved, and upregulate ZIP transporters in an effort to compensate. A model outlining the findings of the present study and potential hypotheses is included in Fig. 6. In conclusion, repeated exposure to coccidial challenge decreased free intracellular $\mathrm{Zn}$, and concurrently increased the ratio of measured ZIP:ZnT transporters. This response appears to be a compensatory effect for reductions in intracellular-free $\mathrm{Zn}$.

\section{Acknowledgements}

The authors would like to thank Zhengyu Jiang and Liting Xu for their assistance with tissue processing and sample preparation during the flow cytometry experiments. We also thank Kolapo Ajuwon for the generous use of his lab facilities and expertise with PCR analysis. The authors thank Zinpro Corporation (Eden Prarie, Minnesota, USA) for partial funding for the present research.

Partial funding for the present research reported herein was provided by the Zinpro Corporation, Eden Prairie, MN, USA as an unconditional research gift. Zinpro Corporation had no role in the design, analysis or writing of this article. Mention of trade names or commercial products in this publication is solely for the purpose of providing specific information and does not imply recommendation or endorsement by the United States Department of Agriculture. United States Department of Agriculture is an equal opportunity employer.

The authors' contributions are as follows: C. T., S. D. E., and T. J. A. were responsible for the design of the research; C. T. carried out the research and prepared the manuscript; C. T., S. D. E., and T. J. A. reviewed and edited the manuscript. All authors read and approved the final version of the manuscript.

The authors have no conflicts of interest to declare.

\section{References}

1. Adams CH, Vahl A \& Veldman A (1996) Interaction between nutrition and Eimeria acervulina infection in broiler chickens: development of an experimental infection model. Br J Nutr 75, 867-873.
2. Williams RB (1999) A compartmentalized model for the estimation of the cost of coccidiosis to the world's chicken production industry. Int J Parasitol 29, 1209-1229.

3. Ruff MD \& Wilkins GC (1980) Total intestinal absorption of glucose and L-methionine in broilers infected with Eimeria acervulina, E. mivati, E. maxima or E. brunetti. Parasitology 80, 555-569.

4. Russell J Jr \& Ruff MD (1978) Disaccharidase activity in the intestinal tissue of broilers infected with coccidia. J Parasitol 64, 706-711.

5. Southern LL \& Baker DH (1983) Eimeria acervulina infection in chicks fed deficient levels of manganese. J Nutr 113, 172-177.

6. Southern LL \& Baker DH (1983) Eimeria acervulina infection and the zinc-copper interrelationship in the chick. Poult Sci 62, 401-404.

7. Bafundo KW, Baker DH \& Fitzgerald PR (1984) The iron-zinc interrelationship in the chick as influenced by Eimeria acervulina infection. J Nutr 114, 1306-1312.

8. Southern LL \& Baker DH (1983) Zinc toxicity, zinc deficiency and zinc-copper interrelationship in Eimeria acervulinainfected chicks. J Nutr 113, 688-696.

9. Turk DE \& Stephens JF (1966) Effect of intestinal damage produced by Eimeria necatrix infection in chicks upon absorption of orally administered zinc-65. J Nutr $\mathbf{8 8}$, 261-266.

10. Turk DE (1986) Microelements in the circulation of coccidiosis-infected chicks. Poult Sci 65, 2098-2103.

11. Turk DE \& Stephens JF (1967) Upper intestinal tract infection produced by $E$. acervulina and absorption of ${ }^{65} \mathrm{Zn}$ and ${ }^{131}$ I-labeled oleic acid. J Nutr 93, 161-165.

12. Richards MP \& Augustine PC (1988) Serum and liver, zinc, copper, and iron in chicks infected with Eimeria acervulina or Eimeria tenella. Biol Trace Elem Res 17, 207-219.

13. Andrews GK (2000) Regulation of metallothionein gene expression by oxidative stress and metal ions. Biochem Pharm 59, 95-104.

14. Ghoshal K, Majumder S, Zhu Q, et al. (2001) Influenza virus infection induces metallothionein gene expression in the mouse liver and lung by overlapping but distinct molecular mechanisms. Mol Cell Biol 21, 8301-8317.

15. Lahiri A \& Abraham C (2014) Activation of pattern recognition receptors up-regulates metallothioneins, thereby increasing intracellular accumulation of zinc, autophagy, and bacterial clearance by macrophages. Gastroenterology 147 , 835-846.

16. Etzel KR, Swerdel MR, Swerdel JN, et al. (1982) Endotoxininduced changes in copper and zinc metabolism in the Syrian hamster. J Nutr 112, 2363-2373.

17. Maitani T \& Suzuki KT (1982) Induction of metallothionein in liver and changes of essential metal levels in selected tissues by three dextran derivatives. Biochem Pharmacol 31, 3051-3055.

18. Klasing KC (1984) Effect of inflammatory agents and interleukin 1 on iron and zinc metabolism. Am J Physiol 247 , R901-R904.

19. Cousins RJ, Liuzzi JP \& Lichten LA (2006) Mammalian zinc transport, trafficking, and signals. $J$ Biol Chem 281, 24085-24089.

20. Wang X \& Zhou B (2010) Dietary zinc absorption: a play of ZIPs and ZnTs in the gut. IUBMB Life 62, 176-182.

21. Wang K, Zhou B, Kuo Y, et al. (2002) A novel member of a zinc transporter family is defective in acrodermatitis enteropathica. Am J Hum Genet 71, 66-73.

22. Liuzzi JP, Bobo JA, Lichten LA, et al. (2004) Responsive transporter genes within the murine intestinal-pancreatic 
axis form a basis of zinc homeostasis. Proc Natl Acad Sci US A 101, 14355-14360.

23. McMahon RJ \& Cousins RJ (1998) Regulation of the zinc transporter ZnT-1 by dietary zinc. Proc Natl Acad Sci U S A 95, 4841-4846.

24. Matsuura W, Yamazaki T, Yamaguchi-Iwai Y, et al. (2009) SLC39A9 (ZIP9) regulates zinc homeostasis in the secretory pathway: characterization of the ZIP subfamily I protein in vertebrate cells. Biosci Biotechnol Biochem 73, 1142-1148.

25. Taniguchi M, Fukunaka A, Hagihara M, et al. (2013) Essential role of the zinc transporter ZIP9/SLC39A9 in regulating the activations of Akt and Erk in B-cell receptor signaling pathway in DT40 Cells. PLOS ONE 8, e58022.

26. Fukada T, Civic N, Furuichi $\mathrm{T}$, et al. (2008) The zinc transporter SLC39A13/ZIP13 is required for connective tissue development; its involvement in BMP/TGF- $\beta$ signaling pathways. PLOS ONE 3, e3642.

27. Jeong J, Walker JM, Wang F, et al. (2012) Promotion of vesicular zinc efflux by ZIP13 and its implications for spondylocheiro dysplastic Ehlers-Danlos syndrome. Proc Natl Acad Sci U S A 109, E3530-E3538.

28. Huang L, Yu Y, Kirschke C, et al. (2007) Znt7 (Slc30a7) deficient mice display reduced body zinc status and body fat accumulation. J Biol Chem 282, 37053-37063.

29. Suzuki T, Ishihara K, Migaki H, et al. (2005) Zinc transporters, ZnT5 and ZnT7, are required for the activation of alkaline phosphatases, zinc-requiring enzymes that are glycosylphosphatidylinositol-anchored to the cytoplasmic membrane. J Biol Chem 280, 637-643.

30. Mizumori M, Ham M, Guth PH, et al. (2009) Intestinal alkaline phosphatase regulates protective surface microclimate $\mathrm{pH}$ in rat duodenum. J Physiol 15, 587-3651.

31. Liuzzi JP, Lichten LA, Rivera S, et al. (2005) Interleukin-6 regulates the zinc transporter Zip14 in liver and contributes to the hypozincemia of the acute-phase response. Proc Natl Acad Sci U S A 102, 6843-6848.

32. Aydemir TB, Chang S, Guthrie G, et al. (2012) Zinc transporter ZIP14 functions in hepatic zinc, iron and glucose homeostasis during the innate immune response (endotoxemia). PLOS ONE 7, e48679.

33. Lopez V \& Kelleher S (2010) Zip6-attenuation promotes epithelial-to-mesenchymal transition in ductal breast tumor (T47D) cells. Exp Cell Res 316, 366-375.

34. Haase H, Ober-Blöbaum JL, Engelhardt G, et al. (2008) Zinc signals are essential for lipopolysaccharide-induced signal transduction in monocytes. J Immunol 181, 6491-6502.

35. Kitamura H, Morikawa H, Kamon H, et al. (2006) Toll-like receptor-mediated regulation of zinc homeostasis influences dendritic cell function. Nat Immunol 7, 971-977.

36. Cousins RJ (1985) Absorption, transport, and hepatic metabolism of copper and zinc: special reference to metallothionein and ceruloplasmin. Phys Rev 65, 238-308.

37. Kehl-Fie TE \& Skaar EP (2010) Nutritional immunity beyond iron: a role for manganese and zinc. Curr Opin Chem Biol 14, 218-224.

38. Corbin BD, Seeley EH, Raab A, et al. (2008) Metal chelation and inhibition of bacterial growth in tissue abscesses. Science 319, 962-965.

39. National Research Council (1994) Nutrient Requirements of Poultry, 9th rev. ed. Washington, DC: National Academy Press.

40. Freitas MG, Porto JL, Lima FC, et al. (2010) Zinc activates neutrophils' oxidative burst. Biometals 23, 31-41.

41. Steinkamp JA, Wilson JS, Saunders GC, et al. (1982) Phagocytosis: flow cytometric quantification with fluorescent microspheres. Science 215, 64-66.
42. Henderson LM \& Chappell JB (1993) Dihydrorhodamine 123: a fluorescent probe for superoxide generation? Eur J Biochem 217, 973-980.

43. Sensi SL, Yin HZ, Carriedo SG, et al. (1999) Preferential Zn ${ }^{2+}$ influx through $\mathrm{Ca}^{2+}$-permeable AMPA/kainate channels trigger prolonged mitochondrial superoxide production. Proc Natl Acad Sci U S A 96, 2414-2419.

44. Aughey E \& Frye FL (2001) Comparative Veterinary Histology with Clinical Correlates. pp. 55-57. London: Manson Publishing.

45. Lee CY, Herant M \& Heinrich V (2011) Target-specific mechanics of phagocytosis: protrusive neutrophil response to zymosan differs from the uptake of antibody-tagged pathogens. J Cell Sci 124, 1106-1114.

46. Pfaffl MW (2001) A new mathematical model for relative quantification in real-time RT-PCR. Nucleic Acids Res 29 , 2002-2007.

47. Pfaffl MW, Tichopad A, Prgomet C, et al. (2004) Determination of stable housekeeping genes, differentially regulated target genes and sample integrity: BestKeeper - Excel-based tool using pair-wise correlations. Biotechnol Lett $\mathbf{2 6}$, 509-515.

48. Rose ME, Hesketh R \& Ogilvie BM (1979) Peripheral blood leukocyte response to coccidial infection: a comparison of the response in rats and chickens and its correlation with resistance to reinfection. Immunology 36, 71-79.

49. Laurent F, Mancassola R, Lacroix S, et al. (2001) Analysis of chicken mucosal immune response to Eimeria tenella and Eimeria maxima infection by quantitative reverse transcription-PCR. Infect Immun 69, 2527-2534.

50. Morel F, Doussiere J \& Vignais PV (1991) The superoxide generating oxidase of phagocytic cells. Eur J Biochem 20, $523-546$.

51. Jeurissen S, Janse E, Vermeulen AN, et al. (1996) Eimeria tenella infection in chickens: aspects of host-parasite interaction. Vet Immunol Immunopathol 54, 231-238.

52. Lillehoj HS (1998) Role of T lymphocytes and cytokines in coccidiosis. Int J Parasitol 28, 1071-1081.

53. Lillehoj HS, Min W \& Dalloul RA (2004) Recent progress on the cytokine regulation of intestinal immune responses to Eimeria. Poult Sci 83, 611-623.

54. Lillehoj HS, Kim CH, Keeler CL, et al. (2007) Immunogenomic approaches to study host immunity to enteric pathogens. Poult Sci 86, 1491-1500.

55. Ranaldi G, Caprini V, Sambuy Y, et al. (2009) Intracellular zinc stores protect the intestinal epithelium from Ochratoxin A toxicity. Toxicol In Vitro 23, 1516-1521.

56. Thambiayya K, Wasserloos KJ, Huang Z, et al. (2011) LPS-induced decrease in intracellular labile zinc, $[\mathrm{Zn}]_{\mathrm{i}}$, contributes to apoptosis in cultured sheep pulmonary artery endothelial cells. Am J Physiol Lung Cell and Mol Phys 300, L624-L632.

57. Dubben S, Hönscheid A, Winkler K, et al. (2010) Cellular zinc homeostasis is a regulator in monocyte differentiation of HL-60 cells by $1 \alpha, 25$-dihydroxyvitamin $\mathrm{D}_{3}$. J Leukoc Biol 87, 833-844.

58. Kim CH, Lillehoj HS, Bliss TW, et al. (2008) Construction and application of an avian intestinal intraepithelial lymphocyte CDNA microarray (AVIELA) for gene expression profiling during Eimeria maxima infection. Vet Immunol Immunopathol 124, 341-354.

59. Dalloul RA, Lillehoj HS, Shellem TA, et al. (2002) Effect of vitamin A deficiency on host intestinal immune response to Eimeria acervulina in broiler chickens. Poult Sci 81, 1509-1515. 
60. Shanmugasundaram R, Sifri M, Selvaraj R, et al. (2013) Effect of yeast cell product supplementation on broiler cecal microflora species and immune responses during an experimental coccidial infection. Poult Sci 92, 1195-1201.

61. Valitutti S, Müller S, Salio M, et al. (1997) Degradation of $\mathrm{T}$ cell receptor (TCR) $-\mathrm{CD} 3 \zeta$ complexes after antigenic stimulation. J Exp Med 185, 1859-1864.

62. Sullivan B \& Coscoy L (2008) Downregulation of the T-cell receptor complex and impairment of T-cell activation by human herpesvirus $6 \mathrm{U} 24$ protein. $J$ Viro 82, 602-608.

63. Göbel TWF \& Dangy J (2000) Evidence for a stepwise evolution of the CD3 family. J Immunol 164, 879-883.

64. Lillehoj HS \& Trout JM (1996) Avian gut-associated lymphoid tissues and intestinal immune responses to Eimeria parasites. Clin Microbiol Rev 9, 349-360.

65. Liu J, Cui H, Peng X, et al. (2013) Decreased IgA + B cells population and IgA, IgG, IgM contents of the cecal tonsil induced by dietary high fluorine in broilers. Int J Environ Res Public Health 10, 1775-1785.
66. Uddin MM, Khan M, Islam K, et al. (2010) Distribution of lymphocytes in the mucosa associated lymphoid tissues (MALT) of naturally occurring infectious bursal disease (IBD) in chicken. Pak Vet J 30, 67-71.

67. Star L, van der Klis JD, Rapp C, et al. (2012) Bioavailability of organic and inorganic zinc sources in male broilers. Poult Sci 91, 3115-3120

68. Guthrie G, Aydemir TB, Troche C, et al. (2014) Influence of ZIP14 (slc39A14) on intestinal zinc processing and barrier function. Am J Physiol Gastrointest Liver Physiol 308, G171-G178.

69. Su S, Miska K, Fetterer R, et al. (2014) Expression of digestive enzymes and nutrient transporters in Eimeria acervulinachallenged layers and broilers. Poult Sci 93, 1217-1226.

70. Castillo M, Martin-Orue SM, Taylor-Pickard JA, et al. (2008) Use of mannanooligosacchardies and zinc chelate as growth promoters and diarrhea preventative in weaning pigs: effects on microbiota and gut function. J Anim Sci 86, $94-101$ 